\title{
MOLYBDENUM STUDIES WITH SHEEP
}

\author{
By \\ GIUMA M. SHERIHA \\ Bachelor of Science \\ Cairo University \\ Cairo, Bgypt
}

1957

Submitted to the faculty of the Graduate School of the Oklahoma State University of Agriculture and Applied Science in partial fulfillment of the requirements for the degree of MASTER OF SCIENCE

May, 1961 
MOLYBDENUM STUDIES WITH SHEEP

Thesis Approved:

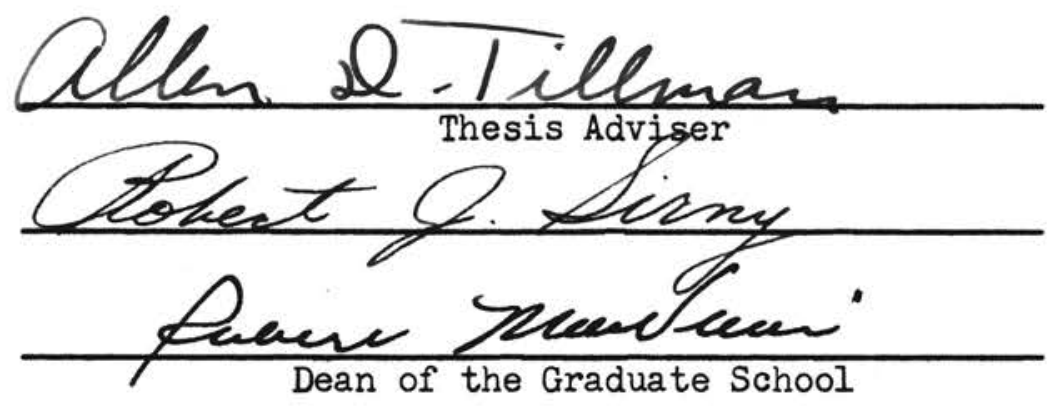




\section{ACKNONLEDGEMENT}

The author wishes to express his deep appreciation to Dr. A. D. Tillman, Professor in the Department of Animal Husbandry, for his valuable suggestions in planning and carrying out these studies and in writing this thesis,

Grateful acknowledgement is also extended to Dr. R. J. Sirny, Associate Professor in the Department of Biochemistry for his invaluable assistance in determining the molybdenum content of the basal rations fed in these studies. 
TABLE OF CONTENTS

Page

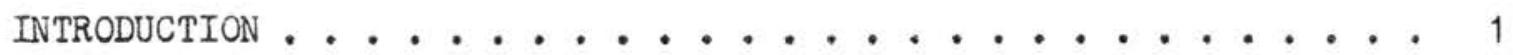

REVIEW OF LITERATURE .................. 2

Molybdenum Toxicity in Ruminants . . . . . . . . . . 2

Molybdenum, Copper, Sulfur, and Phosphorus Interactions. . . . 4

Molybdenum and Xanthine Oxidase ............ ?

Molybdenum as a Dietary Essential for Growth . . . . . . 13

EXPERIMENT I . . . . . . . . . . . . . 15

Experimental Procedure . . . . . . . . . 15

Results and Discussion.............. 17

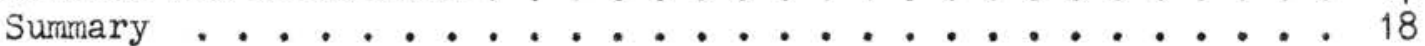

EXPERIMENT II . . . . . . . . . . . . . 19

Experimental Procedure . . . . . . . . . . . 19

Results and Discussion . . . . . . . . . . . 21

Summary ................ 22

EXPERIVENT III................... 23

Experimental Procedure . . . . . . . . . . . 23

Results and Discussion ............. 24

Sumary. . . . . . . . . . . . . . . 25

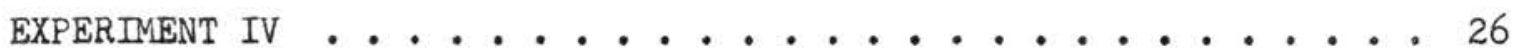

Experimental Procedure .............. . . 26

Results and Discussion .............. 26 26

Summary ................. . . 29

EXPERIMENT V. . . . . . . . . . . . . . . . 30

Experimental Procedure . . . . . . . . . . . 30

Results and Discussion... . . . . . . . . . . 31

Summary ...................... 32

LITERATURE CITED . . . . . . . . . . . . . . 33 


\section{LIST OF TABLES}

Table

Page

I. Percentage Composition of the Semi-Purified Ration . . . . 16

II. Percentage Composition of the Mineral Mixtures . . . . . 16

III. Mean Weight Gains of Lambs Fed Semi-Purified Rations With and Without Added Molybdenum ......... 18

IV. Percentage Composition of the Semi-Purified Ration . . . . 20

V. Percentage Composition of the Mineral Mixtures . . . . . 20

VI, Mean Weight Gains of Lambs Fed Semi-Purified Rations With and Without Added Molybdenum . . . . . . . . 22

VII. Nean Weight Gains of Lambs Fed Semi-Purified Rations With and Without Added Tungsten . . . . . . . . 24

VIII. Percentage Composition of the Purified Ration . . . . . 2 ?

IX. Percentage Composition of the Mineral Mixtures . . . . . 27

X. Mean Weight Gains of Lambs Fed Purified Ration With and Without Added Molybdenum . . . . . . . . 28

XI. Mean Weight Gains of Lambs Fed Semi-Purified Rations With and Without Added Molybdenum . . . . . . . . 31 


\section{INTRODUCTION}

Molybdenum is one of the latest mineral elements to be found essential for microorganisms and plants. Recent experimental evidence suggests that molybdenum might have to be added to the growing list of trace minerals essential for growth and well-being of higher forms of animal life. The purpose of the present studies was to determine the essentiality of molybdenum for sheep. 


\section{REVIEN OF LITERATURE}

Molybdenum Toxicity in Ruminants

Ferguson et al. (1938) discovered that naturally occuring molybdenum in certain pastures in the United Kingdom was responsible for a severe disease of cattle and sheep. The unhealthy pastures were characterized by a molybdenum content of 20 to 100 p.p.m., on the dry basis, as compared to less than 5 p.p.m. in the normal pasture. A large area under pasture in Somerest cannot be grazed by cows during the normal grazing season (April-October) without milk yields falling rapidly, marked loss of condition and even death. The disorder, which has been known for very many years, is marked by extreme diarrhea. Other cattle and sheep also scour on such herbage, though the loss of condition is not so obvious as with milking animals. Such fields are described as being "teart".

Ferguson et al. (1943) reported that the scouring of cattle and sheep caused by the teart pastures can be prevented and cured by feeding or drenching with copper sulfate. A daily dose of 2 grams copper sulfate for cows and 1 gram for young stock is sufficient to cure and prevent the scouring on very teart lands; less copper sulfate being enough on mildly teart land.

Lewis (1943) showed that teart soils contain molybdenum in amounts varying from 0.002 to 0.01 percent in the surface horizon and are neutral or alkaline in reaction and are often calcareous. Those soils, which are 
acid in reaction in the surface horizons, are not teart even if their molybdenum content is high.

Briton et al. (1946) reported that excessive amounts of molybdenum were found in the forage and in the viscera of affected cattle in a localized area of Kern County, California. Present knowledge of chronic molybdenum poisoning justifies the assumption that the disease observed in these young animals resulted from the ingestion of excessive amounts of molybdenum in the forage. A portion of the disease, as observed in the field, was reproduced by administering daily doses of sodium molybdate to a heifer calf.

Barshad (1948) found that legumes growing on soils in the San Joaquin of California, where cattle are abnormally affected, apparently always contain abnormally high amounts of molybdenum.

The molybdenum content of legumes and non-legumes alike appears to increase with the age of the plant. The molybdenum content of soils, which produce teartness in cattle is only slightly higher than is normally found in soils. The solubility of molybdenum is relatively high and the alkalinity of these soils seems to be partly responsible for the high solubility.

Cunningham (1950) demonstrated that copper deficiency in New Zealand occurs on peat soils and on leached soils such as coastal sands and river silts. Disease in cattle and sheep in some regions result from a quantitative deficiency of copper, in others from a copper deficiency which seems to be complicated, induced by an excess of molybdenum in the food.

Simple deficiency in cattle is characterized by a lack of thrift, anemia, and brittleness of bone of young animals while animals showing 
the complicated deficiency exhibit these symptoms accompanied by severe seasonal diarrhea. Deficiency of both types in sheep produce symptoms only in lambs, which develop osteoporosis or ataxia. Molybdenum is regarded as the complicating factor, as it is present in food in an amount which has been shown experimentally to account for the complication. Supplying copper, preferably by topdressing pastures annually with five pounds of bluestone per acre prevents diseases following both types of deficiency.

Thomas et al. (1951) observed that when sodium molybdate was fed to two Holstein calves, the usual symptoms of molybdenum poisoning were observed. In addition, lameness, joint involvement and lack of sexual interest or libido were noted in these two animals. Histological examination of testes showed marked damage to interstitial cells and the germinal epithelium with little or no spermatogenesis taking place.

\section{Molybdenum, Copper, Sulfur, and}

\section{Phosphorus Interactions}

Dick et al. (1945) reported on the analysis of the livers of six ewes maintained over a period of 3 -years on a high molybdenum intake. When the intake of molybdenum was increased by $10 \mathrm{mgm}$. or $100 \mathrm{mgm}$. per day, the copper concentration in the liver was significantly reduced. This also occured when copper was added to the diet. These results suga gest the possibility of increased molybdenum content of pasture being re sponsible for copper deficiency in sheep in some areas of the world.

Davis et al. (1947) demonstrated, in studies with copper deficient Devon cattle, that the alkaline blood phosphatase values increased as copper values decreased. Paralleling the increased phosphatase values, 
blood inorganic phosphorus values roṣe from below 6 to over $12 \mathrm{mg}$. pe. cent. Accompanying this rise, the bones became brittle and young animals exhibited symptoms similar to those noted when ascorbic acid is deficient. Blood ascorbic acid changes, however, were not sufficiently marked to relate them to changes observed in animals. Copper administration quickly restored the phosphatase and blood inorganic phosphorus values to normal.

Comar et al. (1949) showed that molybdenum was accumulated in the bone at about the same rate as phosphorus. They also found that molybdenum tends to reduce the copper storage in the liver and that its toxicity is apparently overcome by administration of excess copper. Alkaline blood phosphatase values of cattle were raised when malybdenum-copper imbalance exists. Perhaps the action of molybdenum may be due to an indirect interference in the enzyme systems necessary for bone development because of lowered levels of copper in the liver and also by a possible direct poisoning effect, as has been observed wịth certain phosphatases. Davis (1950) pointed out that in the herbivorous animals the presence of small amounts of molybdenum ranging from 2 to 25 p.p.m. in young forage, has been associated with an increased requirement for copper and changed metabolism of bone, apparently associated with phosphorus metabolism. Increasing the phosphorus level has not corrected the deficiency which has developed, but additional copper does. It has been difficult to ascertain whether the presence of molybdenum is the sole cause of lowered hemoglobin values or the sole reason for the increased requirement of copper. The possibility that a third element is involved cannot be entirely eliminated.

Dick (1952) found that the group mean value of blood molybdenum 
rising from 48 to $447 \mathrm{mgm}$. per $100 \mathrm{ml}$. blood according to the proportion of oaten chaff (low in sulfur) in the diet. Analyses showed that there was only a slight rise in copper content of the liver in the group which had consumed lucerne (high in sulfur), but that from the group to group, there was a consistently greater amount of copper stored as a proportion of oaten chaff in the diet was increased.

Dick (1953a) reported that when sulfate intake is increased, large quantities of molybdate are excreted particularly in the urine, and the level of molybdenum in the blood falls sharply. The difference between the effects of chaffed lucerne and oaten hays on the blood level is attributed to the difference in their contents of inorganic sulfate. Dick (1953b) found that molybdenum limits copper storage in the liver of sheep only when adequate inorganic sulfate is present in the diet. The differences in contents of sulfate between lucerne and oaten hays was the major reason for the limitation of copper storage by molybdenum in sheep on lucerne diet and, of course, the absence of this limitation in sheep on an oaten diet explains the results obtained. When sulfate intake of sheep is approximately $2 \mathrm{gm}$. per day, as little as .05 mgm. molybdenum per day will significantly limit copper storage. Dick (1954) reported that, when the molybdenum intake of sheep is raised to high levels, the concentration of copper in the blood is increased if the diet contains inorganic sulfate.

When the intake of sulfur is constant, the amount of rise in blood copper level is dependent upon the intake, within the range of 15 to 90 mgm. per day, of molybdenum. The rise in copper level in the blood is also dependent upon the intake of sulfate when molybdenum is fed within the range of 15 to $90 \mathrm{mgm}$. per day. On the evidence of the development 
of a "steely wool" condition associated with the rise in blood copper level, the suggestion was made that a large proportion of circulating copper is not available to the enzyme systems concerned with the development of fleece character, and that the higher intakes of molybdenum and sulfate produce a "physiological" copper deficiency in sheep. Dick (1955) demonstrated that a sheep on a constant molybdenum intake, given a dose of an inorganic sulfate either by mouth or parenterally would excrete greater quantities of molybdenum in the urine while the blood molybdenum concentration would fall. The rate of molybdenum loss in the urine during the first 48 hours after administration of sulfate greatly exceeded intake during this period and accounted for the fall in the blood molybdenum; the amount of molybdenum excreted in the feces is also found to be increased by administration of sulfate. Wynne et al. (1955) fed sheep mixed diets, with wheat hay as the main constituent, containing 6 p.p.m. of copper, 0.7 or 5 p.p.m. of malybdenum and .04 or 0.4 percent of sulfate. After 4 months, the sheep on high sulfate intake with either molybdenum level showed the greatest fall in liver copper and higher blood copper levels. Sheep on restricted feed intake, receiving only half the amount eaten by the group on highest molybdenum and sulfate intake, also had low levels of liver copper indicating that the ratio of these substances was therefore more important than absolute intake.

\section{Molybdenum and Xanthine Oxidase}

Easterfield et al. (1929) reported that the occurence of xanthine calculi in the kidneys of sheep on certain poor pastures. The incidence of xanthine calculi seemed to be associated with poor results with sheep 
over large areas. Poor lambing returns, high mortality of sheep in certain seasons, low milk yields and inability to fatten stock are common features of many farms on the Moutere Hill soil. These workers raised questions regarding the possible effect of mineral deficiency upon purine metabolism.

1. Can a deficiency of certain elements in the soil increase the formation of xanthine or its precursors in the fodder?

2. Can unbalanced mineral ratio cause a partial or complete arrest of purine metabolism at the xanthine stage by reducing the secretion or activity of xanthine oxidase?

Ball (1939) found that the prosthetic group of xanthine oxidase may be split off from the protein reversibly. Its solutions are yellow in color, flouresces strongly, and possess the characteristic absorption spectrum of a flavin with two bands centered at wave lengths of 375 and 450 millimicrons.

It can be converted to lumiflavin derivative, which is identical with that obtained from riboflavin. Its functions quantitatively as the co-enzyme of amino acid-oxidase and possesses other properties in common with this flavin adenine dinuleotide (FAD). The active group of xanthine oxidase is apparently, however, not identical with the amino acid-oxidase co-enzyme.

Axelrod et al. (1941) demonstrated that xanthine oxidase activity of rat liver is greatly diminished in riboflavin deficiency. FAD therapy administered to rats whose food intake is restricted, restores the xanthine oxidase activity to its normal value. Restoration of the enzyme is not as complete in rats fed ad libitum. Evidence showed that the protein component of xanthine oxidase is diminished in FAD deficiency. It is believed, however, that the diminution of the protein constituent is a result of the lowered content of prosthetic group. 
McQuarie et al. (1945) pointed out that the measured xanthine oxidase activity of rat liver is decreased approximately 50 percent ( 1420 to $745 \mathrm{cmm} .0_{2}$ per $\mathrm{hr}$. per gm. per dry tissue) when the protein in animal diet is reduced from 25 percent to 20 percent. When the protein level is lowered to 10 percent, the measurable xanthine oxidase activity is almost, if not completely, lost.

Westerfeld et al. (1949) showed that the average xanthine oxidase activities, in cmm. $\mathrm{O}_{2}$ per gm. per dry wt. per $\mathrm{hr}$. for adult rat tissues were: liver, 1862; small intestines, 628; spleen, 534; lung, 479; kidney, 135; stomach, 42; skin, 100 to 200; brain, 0; muscle, 0; and testes, 0. Two-thirds of the total activity in the entire rat was in liver. Methylene blue added to the Warburg flask in the aerobic determination increased the xanthine oxidase activity in liver, kidney, stomach, and small intestine, but not in lung or spleen. As the liver xanthine oxidase was depleted by a purified low protein diet, the small intestine lost about two-thirds of its activity and the lung lost about one-half; losses from the spleen and kidney were small. The entire rat lost threefourths or more of its xanthine oxidase activity.

Bass et al. (1950) found that the depletion of liver xanthine oxidase by feeding adult or weanling rats a purified, 8 percent casein, diet did not interfere with the formation and excretion of normal amounts of uric acid and allantoin. Addition of p-di-methyl-amino-azobenzene to the diet was also without effect on this excretion.

Westerfeld et al. (1950) demonstrated that a preparation of xanthine oxidase from milk and liver contained an unknown substance in the prosthetic group in addition to FAD. Approximately one-third of the absorption at wave length 450 millimicrons was due to flavin, the 
remainder being due to the unknown component. The activity of apoenzyme, prepared by prolonged dialysis of the enzyme was restored by a co-enzyme extracted by xanthine oxidase but not by FAD or flavin phos. phate, thus some unidentified factor other than FAD or flavin mononucleotide must be supplied in the diet in order for weanling rats to deposit and retain normal levels of xanthine oxidase in liver.

De Renzo (1954) produced molybdenum deficient weanling rats, which were then given a single subcutaneous injection of $40 \mathrm{mcgm}$. molybdenum and sacrificed by at 1,4 , and 8 hours after injection. The intestines were removed and xanthine oxidase was determined. At zero hour, the xanthine oxidase value was 8.3 microliters of $\mathrm{O}_{2}$ uptake per 20 min. per $250 \mathrm{mgm}$. intestine. The value observed at 1, 4, and 8 hours after injection was $14.3,17.7$, and 20.8 , respectively. In contrast, the in jection of vitamin $\mathrm{B}_{12}$ into deficient rats has been reported to increase the liver xanthine oxidase only after a period of 8 days indicating only an indirect participation of vitamin $\mathrm{B}_{12}$ of the formation of xanthine oxidase in tissue. By analogy, the rapid formation of xanthine oxidase after molybdenum administration is interpreted as a direct participation of molybdenum in the formation of enzyme. This can be viewed as a metallo-prosthetic group with the remainder of the enzyme. Richert et al. (1953) showed that the dietary factor required for the deposition and maintenance of normal levels of rat intestinal xanthine oxidase was isolated from soyflour and identified as a molybdenum salt. Sodium molybdate gave saturation levels of intestinal xanthine oxidase when the diet contained less than $0.1 \mathrm{mgm}$. of Mo per $\mathrm{kgm}$. The best assay range was 20 to $60 \mathrm{mcgm}$. of molybdenum per $\mathrm{kgm}$. of diet. All biological activity of the isolated material could be accounted for by 
the molybdenum present.

Totter et al. (1953) reported that isolation and purification of xanthine oxidase from the milk of cows fed radioactive molybdenum, provided evidence that molybdenum is an integral part of xanthine oxidase of milk. Green et al. (1953) reported that there are two molecules of FAD and one atom of molybdenum per molecule of xanthine oxidase. The molecular weight of xanthine oxidase was found to be about 230,000.

Richert et al. (1954) demonstrated that both iron and molybdenum are required in the diet simultaneously for the building of intestinal xanthine oxidase. The omission of iron from purified 24 percent casein diets tended to prevent or minimize the response of the intestinal enzyme to 20 , 40 , or $60 \mathrm{mcgm}$. of molybdenum per $\mathrm{kgm}$. of diet. Purified milk xanthine oxidase contained iron, FAD and molybdenum in a ratio of $8: 2: 1$ and had a minimum molecular weight of approximately 320,000. Xanthine oxidase is also found in the liver, spleen, kidney, and small intestine. In the purified state it contains, in addition to protein, FAD, iron and molybdenum and possesses two types of activity. It can act as oxidase utilizing molecular oxygen for the re-oxidation of the reduced $\mathrm{FADH}_{2}$ enzyme, or it can utilize other electron acceptors such as ferri-cytochrome C; in the latter case it acts as dehydrogenase. The substrates for this enzyme are either hypoxanthine or xanthine, which are converted to uric acid.

Healy (1945) working with 49 patients with moderately severe posthemorrhagic or nutritional hypochronic anemia, having an average hemoglobin value of $8.4 \mathrm{gm}$. percent, treated with specially prepared complex molybdenum sequioxide and ferrous sulfate and 21 other patients, having an average hemoglobin value of $8.18 \mathrm{gm}$. percent, treated with 
ferrous sulfate alone, reported normal hemoglobin levels were obtained by all patients in the first group in an average time of 13.7 days with the mean daily increase in hemoglobin of $9.36 \mathrm{gm}$. percent; however, only 2 patients of the group receiving ferrous sulfate alone attained normal hemoglobin levels with a mean daily increase in hemoglobin of $0.12 \mathrm{gm}$. percent. The molybdenum-iron complex also was well tolerated.

Green and Mazur (1957) reported that about 15 percent of the nonporphyrin iron is represented by an unusual iron protein complex called ferritin, which can be obtained in crystalline form containing from 1 ? to 25 percent, by dry weight, of iron. It is found in small quantities in the liver, spleen, and bone marrow, as well as in other organs. Although the bulk of ferritin iron exists in the ferric state and nondialyzable at neutral pH, a small portion of its iron is present at or near surface in ferrous state. This ferrous iron can be removed at neutral $\mathrm{pH}$ in the presence of iron-binding agents such as transferrin. Recent experiments have shown that the reduction of "surface" ferric iron to the ferrous state can be accomplished by the enzyme xanthine dehydrogenase. Its action may be illustrated by the following equation: Xanthine + oxidized enzyme $\longrightarrow$ Uric acid + reduced enzyme Reduced enzyme + ferritin $-\mathrm{Fe}^{+++} \longrightarrow$ 0xidized enzyme + ferritin. $\mathrm{Fe}^{++}+\mathrm{H}^{+}$

In this scheme the reduced flavoprotein enzyme is reduced by xanthine, which is oxidized to uric acid. The reduced enzyme is in turn oxidized by ferric-ferritin, which in turn is reduced to ferrous-ferritin. The ferrous iron of ferritin can now dissociate for combination with transferrin as follows:

$$
\begin{array}{ll}
\text { Ferritin }-\mathrm{Fe}^{++} \rightleftharpoons & \text { Ferritin }+\mathrm{Fe}^{++} . \\
\mathrm{Fe}^{++}+\text {transferrin } & \mathrm{Fe}^{+++}-\text {transferrin. }
\end{array}
$$


These results suggest that the action of xanthine-dehydrogenase may be the normal mechanism for the release of iron from tissue stores.

Molybdenum as a Dietary Essential for Growth

Nicholas et al. (1954) reported that the cell-free extracts of molybdenum deficient Neurospora crassa and Aspergillus niger showed a striking decrease in nitrate-reductase, resulting in an enzyme level ranging from one-tenth to one-thirtieth of the controls. Molybdenum is required by the fungi when nitrate or ammonium nitrate and nitrite is the source of nitrogen. When nitrate serves as the sole nitrogen source, nitrate reductase is not formed and molybdenum requirement is less. The element is therefore also required for metabolic processes other than for reduction of nitrate.

Reisenauer (1956) showed that unnodulated alfalfa plants did not benefit from molybdenum fertilization. Where nodulation was satisfactory increases in yield and nitrogen content of alfalfa hay were attained from molybdenum fertilization. Maximum yield and protein content of alfalfa plant tops were associated with leaf molybdenum levels of 0.5 p.p.m. or more.

Tillman, Sirny and MacVicar (1954) demonstrated that a marked loss in weight was noted in sheep receiving the basal ration and it was found that this condition could be reversed by addition of alfalfa ash. With this technique, a synthetic alfalfa ash promoted weight gain equal to that on natural alfalfa ash, while cobalt resulted in no improvement. Ellis, et al. (1958) found that in two feeding trials, lambs rem ceiving the ration with added molybdenum made significantly faster gains than their controls. 
Reid et al. (1956) demonstrated in two studies with chicks and one study using Broad Breasted Bronze turkey pullets that the addition of molybdenum to purified basal diets resulted in a growth advantage of 13.5 to 19 percent over the unsupplemented group.

Higgins et al. (1956) showed that chicks fed a synthetic diet containing approximately $20 \mathrm{mcgm}$. molybdenum per kgm. developed normally, but the addition of sodium tungstate at a level equivalent to a W:Mo ratio of 1000 to $2000: 1$ produced an apparent molybdenum deficiency. Growth rates were depressed somewhat, and mortality was approximately 25 percent in 5 weeks. All tissue xanthine dehydrogenase and molybdenum concentration were markedly depleted by sodium tungstate, and about onehalf of the uric acid normally excreted by chicks was replaced by a mixture of xanthine and hypoxanthine. All of the effects of 1000:1 sodium tungstate level were completely reversed by adding an additional $2 \mathrm{mgm}$. molybdenum as sodium molybdate per $\mathrm{kgm}$. of diet. They also reported that rats fed $\mathrm{Na}_{2} \mathrm{WO}_{4}$ in a 1000 or 2000:1 ratio of W:Mo grew normally and oxidized xanthine to uric acid and allantoin as well as the controls in spite of the fact that all tissues were depleted of molybdenum and xanthine oxidase; the tissue changes were reversed by addition of dietary $\mathrm{Na}_{2} \mathrm{MOO}_{4}$. 


\section{EXPERIMENT I}

Tefft (1954) reported that three of five sheep receiving a semipurified diet in which minerals were supplied by a simulated alfalfa ash from which molybdenum had been omitted became thin and weak, one becoming so weakened and lame as to necessitate removal from the experiment. Using the same diet, Tillman et al. (1956) were not able to repeat these results. The purpose of this experiment was further study of the effect of omitting molybdenum from a semi-purified diet upon the growth of sheep.

\section{Experimental Procedure}

Semi-purified rations containing mineral mixtures with and without added molybdenum were used in ad libitum feeding trials with female lambs. The composition of the basal ration is shown in Table $I$, and the compositions of the mineral mixtures are shown in Table II. The mineral supplements fed were based on a "synthetic" alfalfa ash (Tillman et al., 1954b), which was compounded from mineral salts to simulate the mineral composition of natural alfalfa ash with the exception of additional phosphorus being added.

Six lambs were used in this experiment; two being fed the basal ration (ration 1 ) while the others received the basal ration plus molybdenum (ration 2) during a 60-day feeding trial. All lambs were housed in individual wooden cages which were designed to reduce extermal contaminants of the distilled water and semi-purified rations. The wooden 
TABLE I

PERCENTAGE COMPOSITION OF THE SEMI-PURIFIED RATION

\begin{tabular}{lr}
\hline Ingredient & \multicolumn{8}{c}{} \\
\hline & \\
Solka Floc Hulls & 37.0 \\
Cottonseed Hures & 3.0 \\
Mineral Mixtures & 6.5 \\
Drackett & 14.8 \\
Starch & 18.8 \\
Cerelose & 18.7 \\
Corn Oil & 1.0 \\
Choline Chloride & 0.1 \\
Vitamin Supplement* & 0.1 \\
\hline
\end{tabular}

* Quadrex type 20, containing 20,000 I.U. vitamin A and 2,500 U.S.P. of D per gram.

TABLE II

PERCENTAGE COMPOSITION OF THE MINERAL MIXTURES

Ingredient

$\mathrm{K}_{2} \mathrm{CO}_{3}$

$\mathrm{CaHPO}_{4}$

$\mathrm{MgSO}_{4}$

$\mathrm{NaCl}$

$\mathrm{FeSO}_{4}$

$\mathrm{MnSO}_{4}$

$\mathrm{Na}_{2} \mathrm{~B}_{4} \mathrm{O}_{7}$

$\mathrm{CuCO}_{3}$

$\mathrm{ZnSO}_{4}$

$\mathrm{CoCl}_{2}$

$\mathrm{MoO}_{3}$

$\mathrm{KI}$
Ration 1

31.55

48.97

10.75

7.43

0.92

0.10

0.19

0.02

0.07

0.001

0.0000

0.003
Ration 2

31.55

48.97

10.75

7.43

0.92

0.10

0.19

0.02

0.07

0.001

0.0008

0.003 
floors, which were built two and one-half feet off the ground, contained many holes three-fourths inches in diameter through which passed most of the feces and urine. Any remaining excreta was removed once daily. Distilled water was provided in 12-quart plastic pails while the feeder was made of wood. Daily feed records and weekly weights were kept on all animals during the entire experiment.

\section{Results and Discussion}

The results of this experiment are summarized in Table III and it is apparent that the omission of molybdenum did not affect gains, thereby confirming the results of Tillman et al. (1956). The results, however, do not confirm those of Tefft (1954). The reason(s) for this diversity of results are not apparent to the writer. It is possible that the 0.45 p.p.m. of molybdenum found in the basal ration supplied enough to meet the requirement of the sheep used in this trial. Also, it is realized that the number of animals used in this trial was small. As the earlier reports by Tefft et al. (1954) indicated very wide treatment differences under conditions less desirable from the standpoint of contamination of feed and water with molybdenum from external sources than those used in the present experiment, it was thought that greater numbers would not be necessary.

In looking for possible reasons for the diverse results obtained when molybdenum is omitted from the diets of sheep, one cannot overlook the possibilities that differences in waters and feeds are possible. Tefft et al. (1954) dispensed the rations and tap water in metal containers in contrast to the more refined procedures used in this trial. It is possible that either the feeds or the waterers used in their 
experiments contained substance(s) which interfered with molybdenum utilization by sheep or the rumen microorganisms. Experiments bearing on these points will be reported subsequently in experiments in this thesis.

TABLE III

MEAN WEIGHT GAINS OF LAMBS FED SEMI-PURIFIED RATIONS WITH AND WITHOUT ADDED MOLYBDENUM

\begin{tabular}{lllllll}
\hline Ration & & $\begin{array}{c}\text { Mean } \\
\text { Initial } \\
\text { Number }\end{array}$ & $\begin{array}{c}\text { Mean } \\
\text { Final } \\
\text { Wt. }\end{array}$ & $\begin{array}{c}\text { Mean } \\
\text { Wt. Gain } \\
(60 \text { Days) }\end{array}$ & $\begin{array}{c}\text { Mean Average } \\
\text { Daily Gain } \\
\text { (60 Days) }\end{array}$ & $\begin{array}{c}\text { Mean } \\
\text { Feed } \\
\text { Efficiency }\end{array}$ \\
\hline 1 & Basal & 44.5 & 61.0 & $16.5(2.9)^{1}$ & 0.28 & $8.00(2.2)^{1}$ \\
2 & Basal+Mo & 45.5 & 64.0 & $18.5(0.0)^{1}$ & 0.31 & $7.23(0.0)^{1}$ \\
\hline
\end{tabular}

$I_{\text {Standard deviation of means. }}$

Summary

Supplemented molybdenum did not improve gains of sheep maintained on semi-purified diets for 60 days. 


\section{EXPERIMENT II}

The results of the first experiment reported in this thesis did not confirm the results of Tefft (1954) even though similar rations fed under more refined conditions were used. As Ellis et al. (1958) also had reported molybdenum deficiency symptoms in lambs maintained under feedlot conditions, it was decided to replicate their experiments using the more refined conditions described in the first experiment of this thesis.

\section{Experimental Procedure}

Semi-purified rations containing a mineral mixture with and without added molybdenum and of the same composition as that of the Missouri rations reported by Ellis et al. (1956), were used in feeding trials with female lambs. The composition of the rations and the mineral mixtures are shown in Tables IV and V. All details of ration preparation as described by Ellis et al. (1956, 1958) were followed in this trial.

Six lambs were used in this experiment; three of them receiving basal rations (ration 1 ) and the others the basal ration supplemented with molybdenum (ration 2). Details of the cages and the method of feeding and watering the sheep were described in Experiment I. Each lamb was offered one $\mathrm{kgm}$. of the diets daily and that portion not consumed was weighed and discarded. 
TABLE IV

PERCENTAGE COMPOSITION OF THE SEMI-PURIFIED RATION

\begin{tabular}{lr}
\hline Ingredient & $\%$ \\
\hline Solka Floc & 19.30 \\
Beet Pulp Plain & 21.70 \\
Casein & 10.30 \\
Mineral Mixtures & 5.22 \\
Starch & 26.68 \\
Cerelose & 14.70 \\
Lard & 2.00 \\
Vitamin Supplement* & 0.10 \\
\hline
\end{tabular}

* Quadrex type 20, containing 20,000 I.U. vitamin A and 2,500 U.S.P. of D per gram.

TABLE V

PERCENTAGE COMPOSITION OF THE MINERAL MIXTURES

Ingredient

$\mathrm{CaHPO}_{4}$

$\mathrm{MaCl}$

$\mathrm{KCl}$

$\mathrm{MgO}$

$\mathrm{Na}_{2} \mathrm{SO}_{4}$

$\mathrm{MnSO} 4 \cdot 4 \mathrm{H}_{2} \mathrm{O}$

$\mathrm{Fe}\left(\mathrm{C}_{6} \mathrm{H}_{5} \mathrm{O} 7\right) \cdot 3 \mathrm{H}_{2} \mathrm{O}$

$\mathrm{ZnCl}_{2}$

$\mathrm{CoSO}_{4} \cdot \mathrm{H}_{2} \mathrm{O}$

$\mathrm{CaF}_{2}$

$\mathrm{Na}_{2} \mathrm{MoO}_{4} \cdot 2 \mathrm{H}_{2} \mathrm{O}$

$\mathrm{Na}_{2} \mathrm{~B}_{4} \mathrm{O} 7$

$\mathrm{KI}$

$\mathrm{CuCO}_{3}$
Ration 1

34.49

19.16

23.00

3.80

18.19

0.236

1.00

0.0169

$0.005 ?$

0.0038

0.0000

0.038

0.020

0.020
Ration 2

34.49

19.16

23.00

3.80

18.19

0.236

1.00

0.0169

0.0057

0.0038

0.0170

0.038

0.020

0.020 
Results and Discussion

The results of this experiment are summarized in Table VI and under the conditions imposed upon the animals supplemental molybdenum did not affect the growth of sheep. Feed efficiencies also were not affected by treatments. Although all conditions except for housing and watering of the sheep were the same as those reported by Ellis et al. (1958), the results of the present experiment do not confirm their results. As their basal ration supplied 0.36 p.p.m. of molybdenum compared to 0.20 p.p.m. found in the basal ration used in the present experiment, the divergent results cannot be explained on the basis of ration molybdenum contents per se. Also, there was very little possibility for molybdenum contamination of feed and water in the present experiment, while the use of tap water and metal containers for dispensing feed and water probably increased the level of molybdenum intake even more in their trials. Thus, it appears possible that the basal ration fed by Ellis et al. (1958) as well as the one used in the present experiment supplied sufficient levels of molybdenum for normal lamb growth, but under the conditions of the experiment by the Missouri workers there were factor(s) in the feed or water inhibiting molybdenum utilization and in this way increased the requirements for this element. In this light it can be visualized that the addition of dietary molybdenum overcame the inhibition and normal growth was resumed. In this connection, Higgins et al. (1956) reported that sodium tungstate inhibited molybdenum utilization by chicks when the ratio of $\mathrm{W}$ :Mo was equivalent to 1000:1. Distilled water, plastic pails for watering, wooden feeders and special housing were used to eliminate molybdenum contamination in the 
present experiment. As the molybdenum content of the basal ration was 0.20 p.p.m. versus 0.36 p.p.m. for the Missouri worker's basal ration, it was suggested that factors other than molybdenum was involved in the diversities of results.

\section{TABLE VI}

MEAN WEIGHT GAINS OF LAMBS FED SEMI-PURIFIED RATIONS

WITH AND WITHOUT ADDED MOLYBDENUM

\begin{tabular}{llccccc}
\hline Ration & & $\begin{array}{c}\text { Mean } \\
\text { Initial } \\
\text { Wt. }\end{array}$ & $\begin{array}{c}\text { Mean } \\
\text { Final } \\
\text { Wt. }\end{array}$ & $\begin{array}{c}\text { Mean } \\
\text { Wt. Gain } \\
\text { (73 Days) }\end{array}$ & $\begin{array}{c}\text { Mean Average } \\
\text { Daily Gain } \\
\text { (73 Days) }\end{array}$ & $\begin{array}{c}\text { Mean } \\
\text { Feed } \\
\text { Efficiency }\end{array}$ \\
\hline & & Ib. & 1b. & 1b. & 1b. & $1 b$. \\
1 & Basal & 35.8 & 63.3 & $27.5(1.8)^{1}$ & 0.38 & $5.4(0.0)^{1}$ \\
2 & Basal+Mo & 35.5 & 62.0 & $26.5(4.8)^{1}$ & 0.36 & $5.7(1.4)^{1}$ \\
\hline
\end{tabular}

${ }^{I_{S t a n d a r d}}$ deviation of means.

The results of further investigation for the factor(s) responsible for the depression of lamb growth rates and which were assumed to be present in the rations or water used by Tefft (1954) and Ellis et al. (1958), will be reported in subsequent experiments.

\section{Summary}

When molybdenum was added to a semi-purified diet, used by other workers (Ellis et al, 1958) to produce molybdenum deficiency symptoms in sheep, it did not affect gains of lambs. 


\section{EXPERIMENT III}

This experiment was undertaken as a first approach to find out if there were factor(s) present in the tap water or/and in the rations of Ellis et al. (1958) responsible for the beneficial effects of supplemental molybdenum. The idea for the first element to investigate as a possible factor(s) came from the work of Higgins et al. (1956) in which they showed that the chicks fed synthetic diet containing approximately 20 mcgm. molybdenum per kgm. developed normally, but the addition of sodium tungstate at a level to give a W:Mo ratio of 1000:l, produced an apparent molybdenum deficiency. Growth rates were depressed and mortality rates increased during a five week trial. The detrimental effects of tungsten were completely reversed by adding an additional two mcgm. molybdenum per $\mathrm{kgm}$. of diet.

The purpose of this experiment was to determine the effects of tungstate when added to a diet deficient in molybdenum, upon the gains and efficiencies of lambs.

\section{Experimental Procedure}

The six lambs used in Experiment II were used in this experiment. Two of these received the basal diet, while four received the basal diet plus $16.3 \mathrm{gm}$. of $\mathrm{Na}_{2} \mathrm{WO}_{4} \cdot 2 \mathrm{H}_{2} \mathrm{O}$ per 100 pounds of diet; this level of tungstate giving a W:Mo ratio of 1000:I respectively. All other details of rations and treatment of animals were described in Experiment II. 
Results and Discussion

The results of this experiment are shown in Table VII. Tungstate addition did not significantly affect gains or feed efficiencies of the lambs; however, there was a slight reduction in gains and feed efficiencies. As was true in Experiments I and II, facilities were limited and the numbers of animals on each ration were small, however, the effects of molybdenum addition to the rations used by Ellis et al. (1958) upon gains and general appearance were so great one would deem greater numbers unnecessary.

\section{TABLE VII}

MEAN WEIGHT GAINS OF LAMBS FED SEMI-PURIFIED RATIONS WITH AND WITHOUT ADDED TUNGSTEN

\begin{tabular}{|c|c|c|c|c|c|c|}
\hline $\begin{array}{l}\text { Ration } \\
\text { Number }\end{array}$ & Ration & $\begin{array}{l}\text { Mean } \\
\text { Initial } \\
\text { Wt. } \\
\end{array}$ & $\begin{array}{l}\text { Mean } \\
\text { Final } \\
\text { Wt. }\end{array}$ & $\begin{array}{l}\text { Mean } \\
\text { Wt. Gain } \\
\text { (56 Days) }\end{array}$ & $\begin{array}{c}\text { Mean Average } \\
\text { Daily Gain } \\
\text { (56 Days) }\end{array}$ & $\begin{array}{c}\text { Mean } \\
\text { Feed } \\
\text { Efficiency }\end{array}$ \\
\hline & & Ib. & Ib. & Ib. & Ib. & Ib. \\
\hline $\begin{array}{l}1 \\
2 \\
\end{array}$ & $\begin{array}{l}\text { Basal } \\
\text { Basal+W }\end{array}$ & $\begin{array}{l}61.3 \\
63.4 \\
\end{array}$ & $\begin{array}{l}76.0 \\
75.9\end{array}$ & $\begin{array}{l}14.8(0.0)^{1} \\
12.5(3.2)^{1}\end{array}$ & $\begin{array}{l}0.27 \\
0.22 \\
\end{array}$ & $\begin{array}{l}8.2(0.0)^{1} \\
9.3(2.9)^{1} \\
\end{array}$ \\
\hline
\end{tabular}

$I_{\text {Standard deviation of means. }}$

In the present experiment the general appearance of the animals were not affected by the addition of tungstate, thereby indicating that the complexing element in the Missouri experiment was not tungsten. With rats as the experimental animals, the results of Higgins et al. (1956) also indicated that these animals were able to grow normally and to oxidize xanthine to allantoin in spite of the fact that all tissues were practially depleted of molybdenum and xanthine oxidase. 
Summary

Feeding tungstate in the ratio of 1000 parts of tungsten to 1 part of molybdenum to sheep receiving a molybdenum deficient diet did not significantly affect gains during a 56-day growth test. 


\section{EXPERIMENT IV}

Since the results of Experiments I, II and III, reported in this thesis, did not confirm the results of Tefft (1954) and by Ellis et al. (1958), which indicated that molybdenum was an essential mineral for sheep, it was thought that the diets might have contained enough residual molybdenum to meet their requirement. The purpose of the present experiment was test for the dietary essentiality of molybdenum for sheep when rations and water contained much lower levels of this element.

\section{Experimental Procedure}

A purified diet (Oltjen et al., 1959) developed at the Oklahoma Station was used in this trial. Its composition and the composition of the mineral mixture are shown in Tables VIII and IX.

Six lambs were used in this experiment; three of them were receiving basal ration (ration 1 ) and the other three the basal ration (ration 2) supplemented with molybdenum. All other details of animal housing and treatment were described in Experiment II, except the distilled water given the sheep was deionized by the use of a Barnstead Banton Demineralizer, Model BD-1 and the animals being fed for 46 days.

\section{Results and Discussion}

The results of this experiment are summarized in Table $\mathrm{X}$. In spite of the more critical conditions of experimentation employed in 
TABLE VIII

PERCENTAGE COMPOSITION OF THE PURIFIED RATION

\begin{tabular}{lc}
\hline Ingredient & \multicolumn{1}{c}{} \\
\hline Solka Floc & 40.0 \\
Mineral Mixtures & 6.5 \\
Urea & 4.2 \\
Starch & 24.2 \\
Cerelose & 24.1 \\
Corn Oil & 1.0 \\
Choline Chloride & 0.1 \\
Vitamin Supplement* & $0.40 \mathrm{gm}$. \\
Vitamin A Acetate & $0.05 \mathrm{gm}$. \\
\hline
\end{tabular}

* Vitamin A acetate containing 1 million units per gram calciferol (granular) containing 850,000 units per gram.

TABLE IX

PERCENTAGE COMPOSITION OF THE MINERAL MIXTURES

\begin{tabular}{lcc}
\hline Ingredient & Ration 1 & Ration 2 \\
\hline $\mathrm{K}_{2} \mathrm{CO}_{3}$ & 31.55 & 31.55 \\
$\mathrm{CaHPO}_{4}$ & 48.97 & 48.97 \\
$\mathrm{MgSO}_{4}$ & 10.75 & 10.75 \\
$\mathrm{NaCl}$ & 7.43 & 7.43 \\
$\mathrm{FeSO}_{4}$ & 0.92 & 0.92 \\
$\mathrm{MnSO}_{4}$ & 0.10 & 0.10 \\
$\mathrm{Na}_{2} \mathrm{~B}_{4} \mathrm{O}$ & 0.19 & 0.19 \\
$\mathrm{CuCO}_{3}$ & 0.02 & 0.02 \\
$\mathrm{ZnSO}_{4}$ & 0.07 & 0.07 \\
$\mathrm{CoCl}_{2}$ & 0.0001 & 0.0001 \\
$\mathrm{Na}_{2} \mathrm{MOO}_{4} \cdot 2 \mathrm{H}_{2} \mathrm{O}$ & 0.000 & 0.0102 \\
$\mathrm{KI}^{2}$ & 0.003 & 0.003 \\
& & \\
\hline
\end{tabular}


this experiment, these results are in complete agreement with those of the three previous experiments. Under these experimental conditions, the results indicate that molybdenum is not essential for growth rates of lambs.

\section{TABLE X}

MEAN WEIGHT GAINS OF LAMBS FED PURIFIED RATION WITH AND WITHOUT ADDED MOLYBDENUM

\begin{tabular}{ccccccc}
\hline Ration & & $\begin{array}{c}\text { Mean } \\
\text { Initial } \\
\text { Number }\end{array}$ & $\begin{array}{c}\text { Mean } \\
\text { Final } \\
\text { Wt. }\end{array}$ & $\begin{array}{c}\text { Mean } \\
\text { Wt. Gain } \\
(46 \text { Days) }\end{array}$ & $\begin{array}{c}\text { Mean Average } \\
\text { Daily Gain } \\
(46 \text { Days) }\end{array}$ & $\begin{array}{c}\text { Mean } \\
\text { Feed } \\
\text { Efficiency }\end{array}$ \\
\hline & & Ib. & 1b. & 1b. & 1b. & $1 \mathrm{~b}$. \\
1 & Basal & 47.2 & 59.0 & $11.8(1.1)^{1}$ & 0.26 & $9.2(1.3)^{1}$ \\
2 & Basal+Mo & 47.0 & 57.7 & $10.7(3.8)^{1}$ & 0.23 & $10.1(2.10)^{1}$ \\
\hline
\end{tabular}

$I_{\text {Standard deviation of means. }}$

Thus, these results as well as those reported in three earlier experiments indicate that molybdenum is not a dietary essential for sheep. As pointed out previously these results do not confirm earlier results obtained by the Oklahoma group (Tefft, 1954) and Missouri workers (Ellis et al., 1958); therefore, it is assumed that there were factor(s) either present in the diets or in the water used by these groups of workers which in some manner increased the molybdenum requirements of their animals. In the case of the latter group of workers supplemental molybdenum, it is assumed, overcame the inhibition and growth rate was stimulated. This seems to be the only logical explanation and is used for the basis of a subsequent experiment. 


\section{Summary}

Sheep fed a purified diet in which urea was the sole source of ration nitrogen and deionized distilled water under conditions which greatly minimized the possibilities of molybdenum contamination did not require a supplemental molybdenum for normal growth. 


\section{EXPERIMENT V}

Many workers have shown that molybdenum is a constituent of nitrate reductase, an enzyme which catalyses in some bacteria, fungi and green plants the reduction of nitrate to nitrite. Thus, it is feasible to assume that rumen bacteria can utilize some nitrates as a nitrogen source and that the presence of nitrates in feeds could increase the molybdenum requirements of bacteria directly and the requirement of the host animal indirectly by this mechanism.

The purpose of this experiment was to determine the effect of added nitrates upon the molybdenum requirements of sheep.

\section{Experimental Procedure}

The semi-purified diet used by Ellis et al. (1958) in their studies and described in Tables IV and V of this thesis was employed in the present experiment with the following exceptions: (1) One percent potassium nitrate was added and the diet was not autoclaved and (2) the nitrate content of the beet pulp, calculated as potassium nitrate, was 0.06 percent.

Six lambs were used in the 50-day test; three received the basal diet (ration 1) while the others received the basal diet (ration 2) supplemented with molybdenum. All other details were as described in Experiment II. 
Results and Discussion

The results of this experiment are summarized in Table XI and were consistent with those of the four experiments reported herein as well as with that reported by Tillman et al. (1956). In other words, under the conditions imposed in all of these experiments, there were no differences in growth rates of lambs receiving basal rations and of those fed basal rations supplemented with molybdenum.

\section{TABLE XI}

MEAN WEIGHT GAINS OF LAMBS FED SEMI-PURIFIED RATIONS

WITH AND WITHOUT ADDED MOLYBDENUM

\begin{tabular}{|c|c|c|c|c|c|c|}
\hline $\begin{array}{l}\text { Ration } \\
\text { Number } \\
\end{array}$ & Ration & $\begin{array}{c}\text { Mean } \\
\text { Initial } \\
\text { Wt. }\end{array}$ & $\begin{array}{l}\text { Mean } \\
\text { Final } \\
\text { Wt. }\end{array}$ & $\begin{array}{l}\text { Mean } \\
\text { Wt. Gain } \\
\text { (50 Days) }\end{array}$ & $\begin{array}{c}\text { Mean Average } \\
\text { Daily Gain } \\
\text { (50 Days) }\end{array}$ & $\begin{array}{l}\text { Mean } \\
\text { Feed } \\
\text { Efficiency }\end{array}$ \\
\hline & & 1b. & Ib. & Ib. & Ib. & Ib. \\
\hline $\begin{array}{l}1 \\
2\end{array}$ & $\begin{array}{l}\text { Basal } \\
\text { Basal+Mo }\end{array}$ & $\begin{array}{l}66.2 \\
66.0\end{array}$ & $\begin{array}{l}72.5 \\
77.2\end{array}$ & $\begin{array}{l}10.8(4.0)^{1} \\
11.2(2.1)^{1}\end{array}$ & $\begin{array}{l}0.22 \\
0.22\end{array}$ & $\begin{array}{l}12.5(4.1)^{1} \\
10.5(3.2)^{1}\end{array}$ \\
\hline
\end{tabular}

${ }^{1}$ Standard deviation of means.

These results could be interpreted to indicate that under no conditions could a dietary requirement by sheep for molybdenum be shown; however, this could be a dangerous assumption at the present time. It would appear to the writer that until all the intermediate biochemical steps involved in the breakdown of nitrate to ammonia and the interactions of these intermediates upon molybdenum and other trace elements are known, no safe conclusion relative to whether nitrate is a factor in the divergent results can be made. 


\section{Summary}

The addition of molybdenum to a semi-purified diet containing one percent potassium nitrate did not affect the performance of growing lambs. The significance of these results are discussed. 


\section{LITERATURE CITED}

Axlerod, A. D., and C. A. Elvehjen, 1941. The xanthine oxidase content of rat liver in riboflavin deficiency. J. Biol. Chem. 140-725.

Ball, E. G., 1939. Xanthine oxidase purification and properties. J. Biol. Chem. 128:51.

Barshad, Issac, 1948. Molybdenum content of pasture plant in relation to toxicity to cattle. Soil Sci. 66:180.

Bass, A. D., J. Tepperman, D. A. Richert, and W. W. Westerfeld, 1950. Excretion of uric acid and allantoin by rat depleted of xanthine oxidase. Proc. Soc. Exp. Biol. Med. 73:687.

Briton, J. W., and H. Goss, 1946. Chronic molybdenum poisoning in cattle. J. Am. Med. Assoc. 108:176.

Comar, C. L., L. Singer, and G. K. Davis, 1949. Molybdenum metabolism and interrelationship with copper and phosphorus. J. Biol. Chem. $180-913$.

Cunningham, I. J., 1950. Copper and molybdenum in relation to disease of cattle and sheep in New Zealand (McElroy, W. D. and B. Glass, A symposium on copper metabolism. John Hopkins Univ. Press, Baltimore, Maryland, p. 246).

Davis, G. K., 1950. The influence of copper on the metabolism of phosphorus and molybdenum (McElroy, W. D. and B. Glass, A symposium on copper metabolism. John Hopkins Univ. Press, Baltimore, Maryland, p. 216).

Davis, G. K., and H. Hannan, Jr., 1947. Copper metabolism with relation to alkaline blood phosphatase and blood ascorbic acid. J. Animal Sci. 6:484.

Dick, A. T., 1952. The effect of diet and molybdenum on copper metabolism in sheep. Aust. Vet. J. 28:30.

Dick, A. T., 1953a. The control of copper storage in the liver of sheep by inorganic sulfate and molybdenum. Aust. Vet. J. 29:233.

Dick, A. .., 1953b. The effect of inorganic sulfate on the excretion of molybdenum on sheep. Aust. Vet. J. 29:18. 
Dick, A. T., 1954. Preliminary observation on the effect of high intake of molybdenum and of inorganic sulfate on blood copper and fleece character in crossbred sheep. Aust. Vet. J. 30:196.

Dick, A. T., 1955. Molybdenum in animal nutrition. Soil Sci. 81:228.

Dick, A. T., and L. B. Bull, 1945. Some preliminary observation on the effect of molybdenum on copper metabolism in herbivorous animals. Aust. Vet. J. 21:70.

De Renzo, E. C., E. Kaleiter, P. Heytler, J. J. Oleson, B. L. Hutchings, and J. H. Williams, 1953. Identification of xanthine oxidase factor as molybdenum. Arch Biochem, and Biophys. 45:247.

De Renzo, E. C., P. G. Heytler, and E. Kaleiter, 1954. Further evidence that molybdenum is a cofactor of xanthine oxidase. Arch. Biochem. and Biophys. 49:242.

Easterfield, T. H., T. Riggs, and H. O. Askew, 1929. A wide spread occurence of xanthine calculi in sheep. J. Agr. Sci. 19:573.

Ellis, W. C., G. B. Garner, M. E. Muhrer, and W. H. Pfander, 1956. Nitrogen utilization by lambs fed purified rations containing urea, gelatin, casein, blood fibrin, and soybean protein. J. Nutr. 60:413.

Ellis, W. C., W. H. Pfander, M. E. Muhrer, and E. E. Pickett, 1958. Molybdenum as a dietary essential for lambs. J. Animal Sci. 17:180.

Ferguson, W. S., A. H. Lewis, and S. J. Watson, 1938. Action of molybdenum in nutrition of milking cattle. Nature 141:553.

Ferguson, W. S., A. H. Lewis, and S. J. Watson, 1943. Teart pastures of somerset I. The cause and cure of teartness. J. Agr. Sci. 33:44.

Green, D. E. and H. Beinert, 1953. Xanthine oxidase, a molybdo-flavoprotein. Biochem. et. Biophys. Acta. 11:599.

Green, S. and A. Mazur, 1957. Relation of uric acid metabolism to release of iron from hepatic ferritin. J. Biol. Chem. 227:653.

Healy, J. C., 1946. Hypochronic anemia. Treatment with molybdenum-iron complex. J. Lancent. 66:218.

Higgins, E. S., D. A. Richert, and W. W. Westerfeld, 1956. Molybdenum deficiency and tungstate inhibition studies. J. Nutr. 59:539.

Lewis, A. H., 1943. The teart pastures of somerset II. Relation between soil and teartness. J. Agr. Sci. 33:52.

McQuarie, E. B., and A. T. Venose, 1945. The effect of dietary protein intake on the xanthine oxidase activity of rat liver. Science 101:493. 
Nicholas, J. D., A. Nason, and W. D. McElroy, 1954. Molybdenum and nitrate reductase I. Effect of molybdenum deficiency on the Neurospora enzyme. J. Biochem. 207:341.

Oltjen, B. R., R. J. Sirny and A. D. Tillman, 1959. Purified diet studies; comparison of four different protein sources in rations for sheep. J. Animal Sci. 18:1522 (Abst.).

Reid, B. L., A. A. Kurnick, R. L. Svacha, and J. R. Couch, 1956. The effect of molybdenum on chick and poultry growth. Proc. Exp. Biol. Med. 93:245.

Reisenaurer, H. M., 1956. Molybdenum content of alfalfa in relation to deficiency symptoms and response to molybdenum fertilization. Soil Sci. 81:237.

Richert, D. A. and W. W. Westerfeld, 1953. Isolation and identification of xanthine oxidase factor as molybdenum. J. Biol. Chem. 203:915.

Richert, D. A. and W. W. Westerfeld, 1954. The relationship of iron to xanthine oxidase factor as molybdenum. J. Biol. Chem. 209:179.

Tefft, C. W., 1954. M. S. Thesis, Oklahoma State University, Stillwater.

Thomas, J. W. and S. Moss, 1951. The effect of orally administered molybdenum on the growth, spermatogenesis and testes histology of young dairy bulls. J. Dairy Sci. 34:429.

Tillman, A. D., R. J. Sirny, and R. MacVicar, 1954. The effect of alfalfa ash upon the digestibility and utilization of cottonseed hulls by sheep. J. Animal Sci. 13:?25.

Tillman, A. D. and R. J. Sirny, 1956. Unpublished data.

Totter, J. R., W. T. Burnett, Jr., R. A. Monroe, Ira B. Whiteney, and C. L. Comar, 1953. Evidence that molybdenum is a nondialyzable component of xanthine oxidase. Science 118:555.

Westerfeld, W. W., and R. A. Richert, 1949. The xanthine oxidase activity of rat tissue. Proc. Soc. Exp. Biol. Med. 71:181.

Westerfeld, W. W. and D. A. Richert, 1950. Dietary factors related to liver xanthine oxidase. J. Biol. Chem. 184:163.

Wynne, K. N. and G. L. McClymont, 1955. Copper-molybdenum-sulfate interaction in induction of hypocuprosis. Nature 175:471. 
VITA

\author{
Giuma M. Sheriha \\ Candidate for the Degree of \\ Master of Science
}

Thesis: MOLYBDENUM STUDIES WITH SHEEP

Major Field: Animal Nutrition

Biographical:

Born: August 25, 1935 at Kabow, Tripoli, Libya.

Undergraduate Study: Cairo University, 1953-1957.

Graduate Study: Oklahoma State University of Agriculture and Applied Science, 1958-1961.

Date of Final Examination: May, 1961. 